\title{
Description of a new subspecies of Carabus (Neoplectes) martviliensis Retezár et Djavelidze, 1992 from Central Georgia (Coleoptera: Carabidae)
}

\section{Описание нового подвида Carabus (Neoplectes) martviliensis Retezár et Djavelidze, 1992 (Coleoptera: Carabidae) из центральной части Грузии}

\author{
D.D. Fominykh', A.S. Zamotajlover, ${ }^{3}$, A.Yu. Titarenko ${ }^{4}$ \\ А.А. Фоминых ${ }^{1}$, А.С. Замотайлов ${ }^{2,3}$, А.Ю. Титаренко ${ }^{4}$
}

\footnotetext{
${ }^{1}$ Russian Entomological Society, Kuban Branch, Kalinin st. 13, Krasnodar 350044, Russia. E-mail: biologne@mail.ru.

${ }^{2}$ I.T. Trubilin Kuban State Agrarian University, Kalinin st. 13, Krasnodar 350044, Russia. E-mail: a zamotajlov@mail.ru.

${ }^{3}$ Adyghei State University, Pervomayskaya st. 208, Maykop 385000, Republic of Adygheya, Russia.

${ }^{4}$ Publicly Traded Company "Morpho Absoloni”, Bolotnikovskaya st. 5/3, Moscow 117556, Russia. E-mail: odindva3@gmail.com.

${ }^{1}$ Русское энтомологическое общество, Кубанское отделение, ул. Калинина, 13, Краснодар 350044, Россия.

2 Кубанский государственный аграрный университет им. И.Т. Трубилина, ул. Калинина, 13, Краснодар 350044, Россия.

3 Адыгейский государственный университет, ул. Первомайская, 208, Майкоп 385000, Республика Адыгея, Россия.

${ }^{4}$ OAO “Morpho Absoloni”, ул. Болотниковская, 5/3, Москва 117556, Россия.
}

KEY WORDS: Coleoptera, Carabidae, Carabus, Neoplectes, Central Georgia, distribution, new subspecies. КЛЮЧЕВЫЕ СЛОВА: Coleoptera, Carabidae, Carabus, Neoplectes, Центральная Грузия, распространение, новый подвид.

ABSTRACT. On the basis of material collected by the authors in 2015-2019 in Central Georgia, a new subspecies Carabus (Neoplectes) martviliensis mzekalae ssp.n. from the vicinities of the town Tskhaltubo is described. Distribution of the known subspecies of $C$. (N.) martviliensis Retezár et Djavelidze, 1992 is discussed.

РЕЗЮМЕ. На основе материала, собранного авторами в 2015-2019 гг. в центральной части Грузии, описывается новый подвид Carabus (Neoplectes) martviliensis mzekalae ssp.n. из окрестностей Цхалтубо. Обсуждается распространение известных подвидов C. (N.) martviliensis Retezár et Djavelidze, 1992.

\section{Introduction}

Carabus (Neoplectes) martviliensis Retezár et Djavelidze, 1992 has been known till now only from the nominotypical subspecies [Retezár, 2015; Březina et al., 2017], with the established geographic range spread from the left bank in the mid-flow of river Tekhuri in the West, through the southern slopes of Ofitsari Mt. Range and Askhi Plateau, to the right bank of river Tskhen- istskali in the East (Fig. 1). It is substituted upstream by the representative of different species-group of $\mathrm{NeO}$ plectes, namely $C$. titarenkoi Zamotajlov et Fominykh, 2014 , both species the most probably occur sympatric between villages Kinchkha and Makhura [Fominykh, Zamotajlov, 2014; Fominykh et al., 2016]. In 2018 a new population of $C$. martviliensis was found on the left bank of river Tskhenistskali, northwards of town Tskhaltubo. 11 individuals collected strikingly differ from populations originated from the other know localities in their colouration, though this number was insufficient for the more definite conclusions and statistical treatment. In 2019 the authors inspected several new localities eastwards of Tskhenistskali valley and revealed new populations, manifesting some constant distinctions from the nominotypical subspecies, a new subspecies is described below from this material.

It is worth of notice, that the entomofauna of Central Georgia, especially of its piedmont and low mountain regions, has recently been experiencing exposure caused primarily by the climate change. Although, above all, this is manifested in the naturalization of alien species, it cannot be ruled out, that the local fauna also reacts to them by expanding species' ranges, growth of the population density, and further speciation.

How to cite this article: Fominykh D.D., Zamotajlov A.S., Titarenko A.Yu. 2019. Description of a new subspecies of Carabus (Neoplectes) martviliensis Retezár et Djavelidze, 1992 from Central Georgia (Coleoptera: Carabidae) // Russian Entomol. J. Vol.28. No.3. P.251-257. doi: 10.15298/rusentj.28.3.03 
Standard methods were applied for treating the material. Endophallus inflation methods generally follow Janovska et al. [2013]. Pictures of the habitus and male genitalia were taken using a Canon EOS 5D, Mark III camera with a Canon MP-E $65 \mathrm{~mm}$ macro photo lens. External characters were studied with the LZOS MBS10 and PZO MST-131 stereoscopes. Digital photographs of the morphological structures were taken by Dr. K. Makarov, live and biotope photographs - by the authors. Measurements were taken using the stereoscopes with an ocular micrometer as follows: general body length (GBL), measured from the tips of mandibles to the elytral apex; standard body length (SBL), measured from the anterior margin of the clypeus to the elytral apex; head width (HW), measured as the maximum linear distance across the head, including the compound eyes; maximum width of pronotum measured at its broadest point (PW); minimum width of pronotum (PB), measured at its narrowest point near the hind angles; length of pronotum (PL), measured along its median line; length of elytra (EL), measured from the basal border in the scutellar region to the apex of the sutural angle; maximum width of the elytra (EW) measured at their broadest point. The following ratios were also measured: $\mathrm{PW} / \mathrm{HW}$; PW/PL; PW/PB; EW/P; EL/EW. All measurements were analyzed using discriminant analysis and graphs produced with STATISTICA data analysis software system (StatSoft Inc., 2010, version 10).

The names of the morphological structures of endophallus generally follow those given by Shilenkov [1996], with some modifications and additions already applied in our previous paper [Fominykh et al., 2016].

The following acronyms are used for the depositories of the specimens examined: ZISP - Zoological Institute of the Russian Academy of Sciences (St. Petersburg, Russia); ZMMU - Zoological Museum of the Moscow State University (Moscow, Russia); MPSU — Moscow Pedagogical State University, Chair of Zoology and Ecology (Moscow, Russia); CFDD - Private collection of D.D. Fominykh (Krasnodar, Russia); CTAY — Private collection of A.Yu. Titarenko (Moscow, Russia); CZAM Private collection of A.S. Zamotajlov (Krasnodar, Russia).

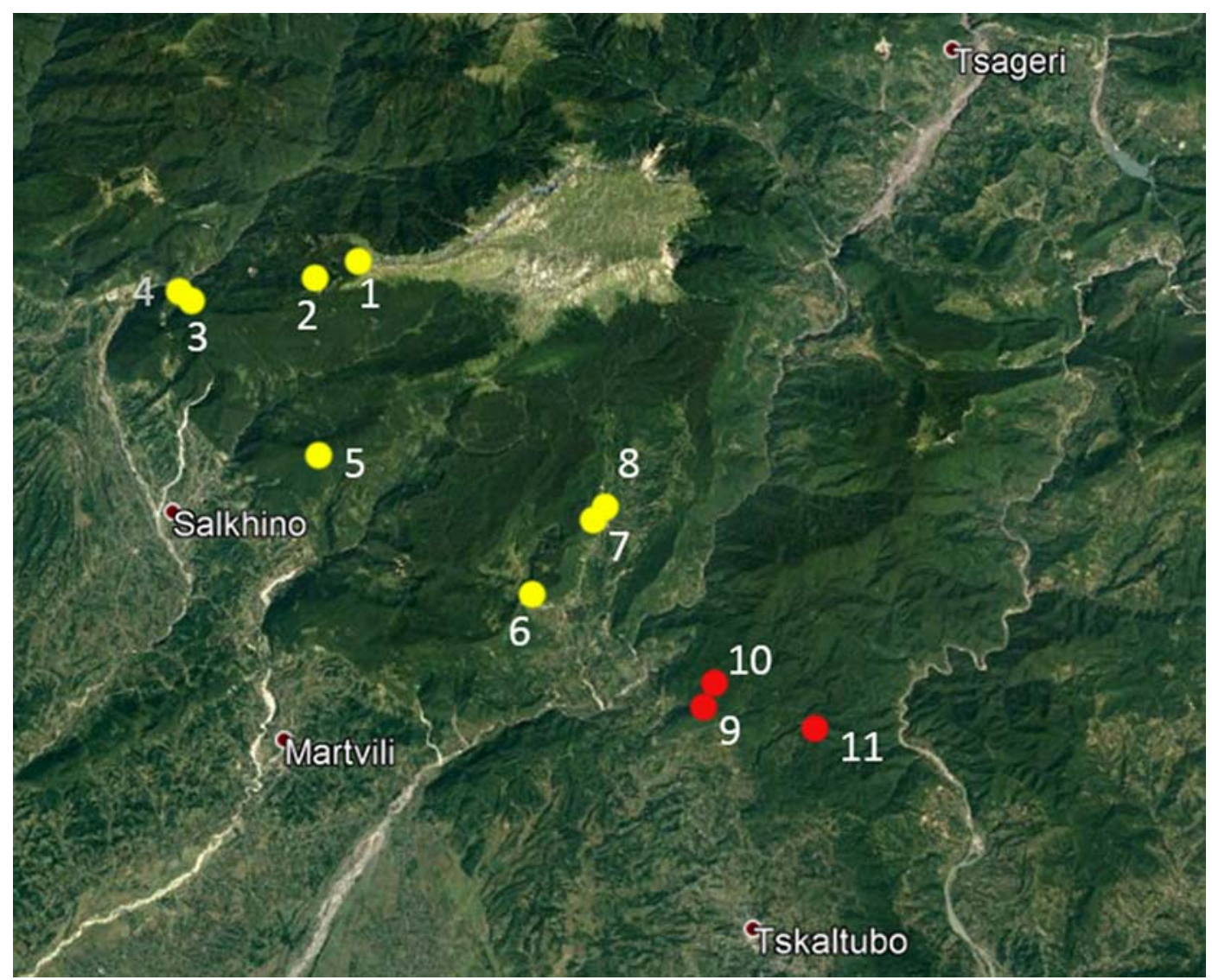

Fig. 1. Studied localities of Carabus (Neoplectes) martviliensis in Central Georgia: 1-8 - C. martviliensis martviliensis; 9-11 - C. martviliensis mzekalae ssp.n.; 1 - Ofitsari Mt. Range, 1900 m; 2 - Ofitsari Mt. Range, 1500 m; 3 - Doberazeni env., 600 m; 4 Doberazeni env., 500 m; 5 - Mt. Muchera, 1009 m; 6 - Zeda Gordi env., 980 m; 7 - Kinchkha-Perdi env., 816 m; 8 - Satziskvilo env., 1000 m; 9 - Dzedzileti env., 520-620 m; 10 - Dzedzileti env., 770 m; 11 - Melouri env., 475 m.

Рис. 1. Изученное распространение Carabus (Neoplectes) martviliensis в центральной части Грузии: 1-8 - C. martviliensis martviliensis; 9-11 - C. martviliensis mzekalae ssp.n.; 1 - хр. Офицари, 1900 м над ур. м.; 2 - хр. Офицари, 1500 м над ур. м.; 3 окр. Доберазени, 600 м над ур. м.; 4 - окр. Доберазени, 500 м над ур. м.; 5 - г. Мучера, 1009 м над ур. м.; 6 - окр. Зеда Горди, 980 м над ур. м.; 7 - окр. Кинчха Перди, 816 м над ур. м.; 8 - окр. Сацисквило, 1000 м над ур. м.; 9 - окр. Дзедзилети, 520-620 м над ур. м.; 10 - окр. Дзедзилети, 770 м над ур. м.; 11 - окр. Мелоури, 475 м над ур. м. 


\section{Results}

Carabus (Neoplectes) martviliensis mzekalae Fominykh, Zamotajlov et Titarenko, ssp.n.

Figs 1-9, 18-19, 22-23, 26-28.

MATERIAL. Holotype $\sigma^{7}$ (ZISP), Georgia, Lechkhumi Mt. Range, left bank of river Tskhenistskali near Dzedzileti, $520 \mathrm{~m}$, 14.V-15.VII.2018, D. Fominykh leg.; Paratypes: $20^{7} 0^{7}, 8$ 우 (CFDD), same data as holotype; $1130^{\top} 0^{\top}, 139$ 우 (MPSU, CFDD, CTAY, CZAM), Imereti, left bank of river Tskhenistskali near Dzedzileti, 620 m, 16.V-13.VII.2019, D. Fominykh, A. Zubov, B. Dubinin \& D. Safronov leg.; $160^{7} 0^{7}, 63$ 우 (MPSU, CFDD, CTAY, CZAM), Imereti, left bank of river Tskhenistskali near Dzedzileti, NW slopes of Mt. Gormagali, 770 m, 15.V-13.VII.2019, D. Fominykh, A.
Zubov, B. Dubinin \& D. Safronov leg.; $490^{7} 0^{7}, 143$ 우 (MPSU, CFDD, CTAY, CZAM), Imereti, left bank of river Semi near Melouri, $475 \mathrm{~m}, 19 . \mathrm{V}-12$.VII.2019, D. Fominykh, A. Zubov, B. Dubinin \& D. Safronov leg.

COMPARATIVE MATERIAL. Carabus (Neoplectes) martviliensis martviliensis Retezár et Djavelidze, 1992: $180^{7} 0^{7}, 22$ 우 (CFDD, CTAY), Georgia, Samegrelo, $3.5 \mathrm{~km}$ of Meore-Balda between Abasha and Chachkheri rivers, SE slopes of Mt. Muchera, 1009 m, 15.IV-20.VI.2015, D. Fominykh \& A. Zubov leg.; $10^{7}$ (CFDD), Samegrelo, Kinchkha-Perdi vic., right bank of river Okatse (=Satsikvilo), $816 \mathrm{~m}, 15 . \mathrm{IV}-20 . \mathrm{VI} .2015$, D. Fominykh \& A. Zubov leg.; 2 오 (CFDD), Imereti, Satziskvilo vic., right bank of river Okatze, 1000 m, 19.IV-12.VI.2016, D. Fominykh leg.; 7 $70^{7}$, 10 우 (CFDD), Imereti, Zeda Gordi vic, right bank of river Tskhenistskali, $1000 \mathrm{~m}, 15 . I V-17 . V I .2017$, D. Fominykh leg.; 81 $0^{7} \mathrm{O}^{7}$, 106우 (CFDD, CTAY, CZAM, MPSU), Imereti, S slopes of Askhi
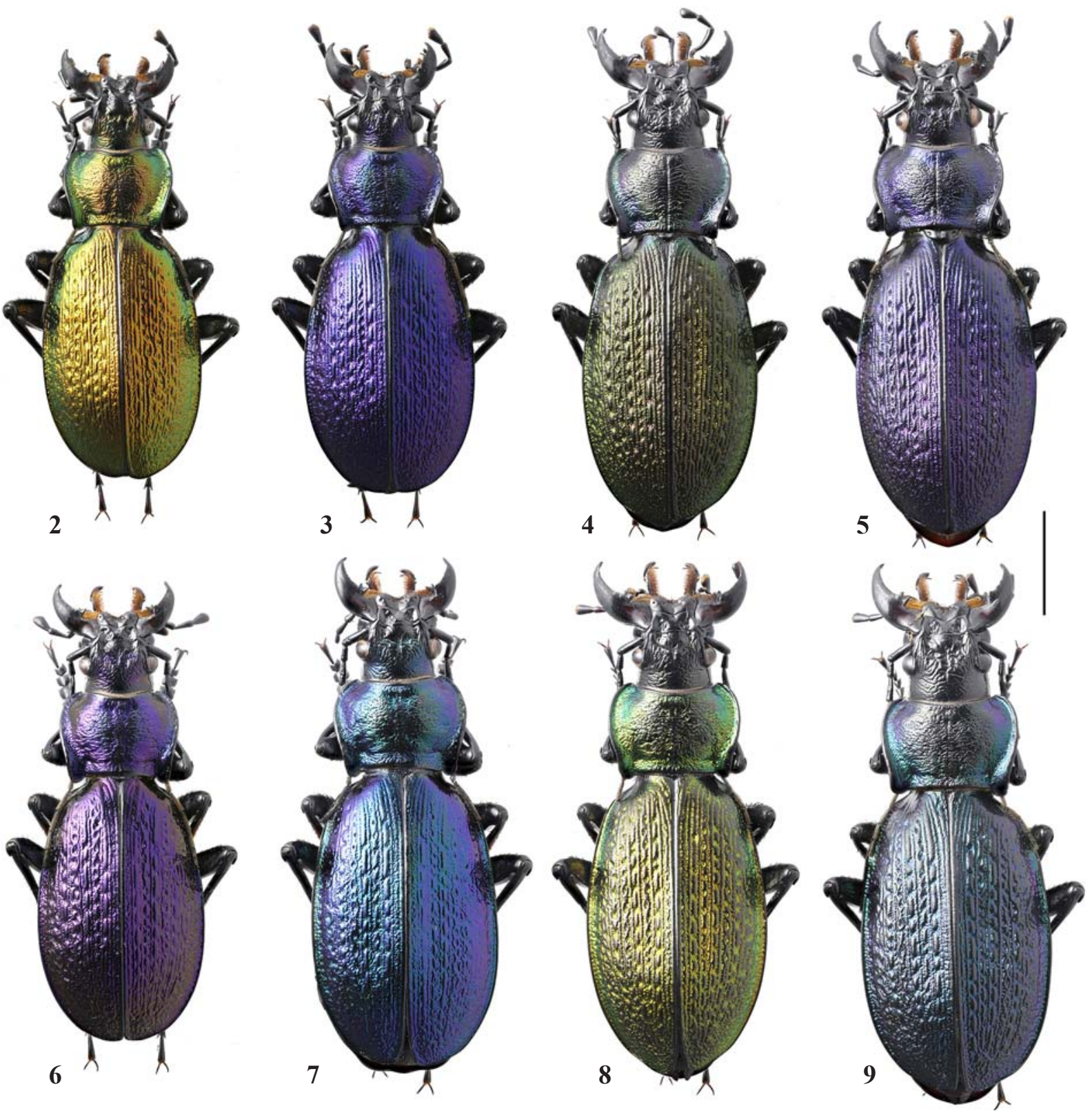

Figs 2-9. Dorsal habitus of Carabus martviliensis mzekalae ssp.n.: 2-5 - Melouri env., 475 m; 6-9 - Dzedzileti env., 770 m; 2-3, 6-7 - males; 4-5, 8-9 - females. Scale bar: $10.0 \mathrm{~mm}$.

Рис. 2-9. Габитус сверху Carabus martviliensis mzekalae ssp.n.: 2-5 - окр. Мелоури, 475 м над ур. м.; 6-9 - окр. Дзедзилети, 770 м над ур. м.; 2-3, 6-7 - самцы; 4-5, 8-9 - самки. Масштаб: 10,0 мм. 
plateau near Zeda-Gordi, NE slope of Mt. Gulkuna, 980 m, 20.V14.VII.2019, D. Fominykh \& A. Zubov leg.; $110^{7} \sigma^{7}$, 6우 (CFDD, CTAY, CZAM, MPSU), Samegrelo, Doberazeni vic., left bank of river Tekhuri, $500 \mathrm{~m}$, 16.IV-31.V.2017, D. Fominykh leg.; 580 $0^{2} \mathrm{O}^{7}$ 84 우 (CFDD, CTAY), Samegrelo, left bank of river Shakvi, N slopes of Ofitsari Mt. Range, 1500 m, 29.V-17.VI.2017, D. Fominykh leg.; $900^{7} 0^{7}, 217$ 우 (CFDD, CTAY), Samegrelo, left bank of river Shakvi, N slopes of Ofitsari Mt. Range, $1900 \mathrm{~m}, 31 . \mathrm{V}-$ 17.VI.2017, D. Fominykh leg.; $1650^{\top} 0^{7}$, 254우 (CFDD, CTAY, CZAM, MPSU), Samegrelo, upper bank of river Shakvi, N slopes of Ofitsari Mt. Range, 1900 m, 2-21.VI.2018, D. Fominykh \& B. Dubinin leg.; $320^{7} 0^{7}, 41$ 오 (CFDD, CTAY), Samegrelo, N slopes of Mt. Ogedzh near Doberazeni, left bank of river Tekhuri, $600 \mathrm{~m}$, 21.V-15.VII.2019, B. Dubinin \& D. Safronov leg.

DESCRIPTION. Big sized subspecies (Figs 2-9).GBL $=38.0-48.5 \mathrm{~mm}$, males $38.0-44.4 \mathrm{~mm}$, females $39.9-48.5$ $\mathrm{mm}, \mathrm{SBL}=36.8-45.0 \mathrm{~mm}$ in both sexes. Underside black, dorsum with metallic luster, both in males and females, violet, blue, less frequently goldish or green, in some individuals with clear iridescence, females somewhat less bright; head mostly black dorsally, sometimes with metallic luster basally; legs, antennae, palpi, and mandibles black. Head thick, somewhat inflated, surface with coarse rugosity, HL $=6.0-7.5 \mathrm{~mm}$ in males, $6.5-8.5 \mathrm{~mm}$ in females, $\mathrm{HW}=6.2-$ $10.8 \mathrm{~mm}$ in males, $7.0-8.6 \mathrm{~mm}$ in females. Pronotum nearly parallel-sided, with coarse rugosity basally, this furrows becoming less pronounced at sides; $\mathrm{PW}=6.4-11.8 \mathrm{~mm}$ in males, $9.8-13.8 \mathrm{~mm}$ in females, $\mathrm{PB}=6.5-8.9 \mathrm{~mm}$ in males, $7.0-9.9 \mathrm{~mm}$ in females, $\mathrm{PL}=5.8-7.2 \mathrm{~mm}$ in males, $6.4-8.0$ $\mathrm{mm}$ in females, $\mathrm{PW} / \mathrm{HW}=0.6-1.6$ in both sexes, PW/PL $=0.9-1.8$ in both sexes, $\mathrm{PW} / \mathrm{PB}=0.8-1.4$ in both sexes;
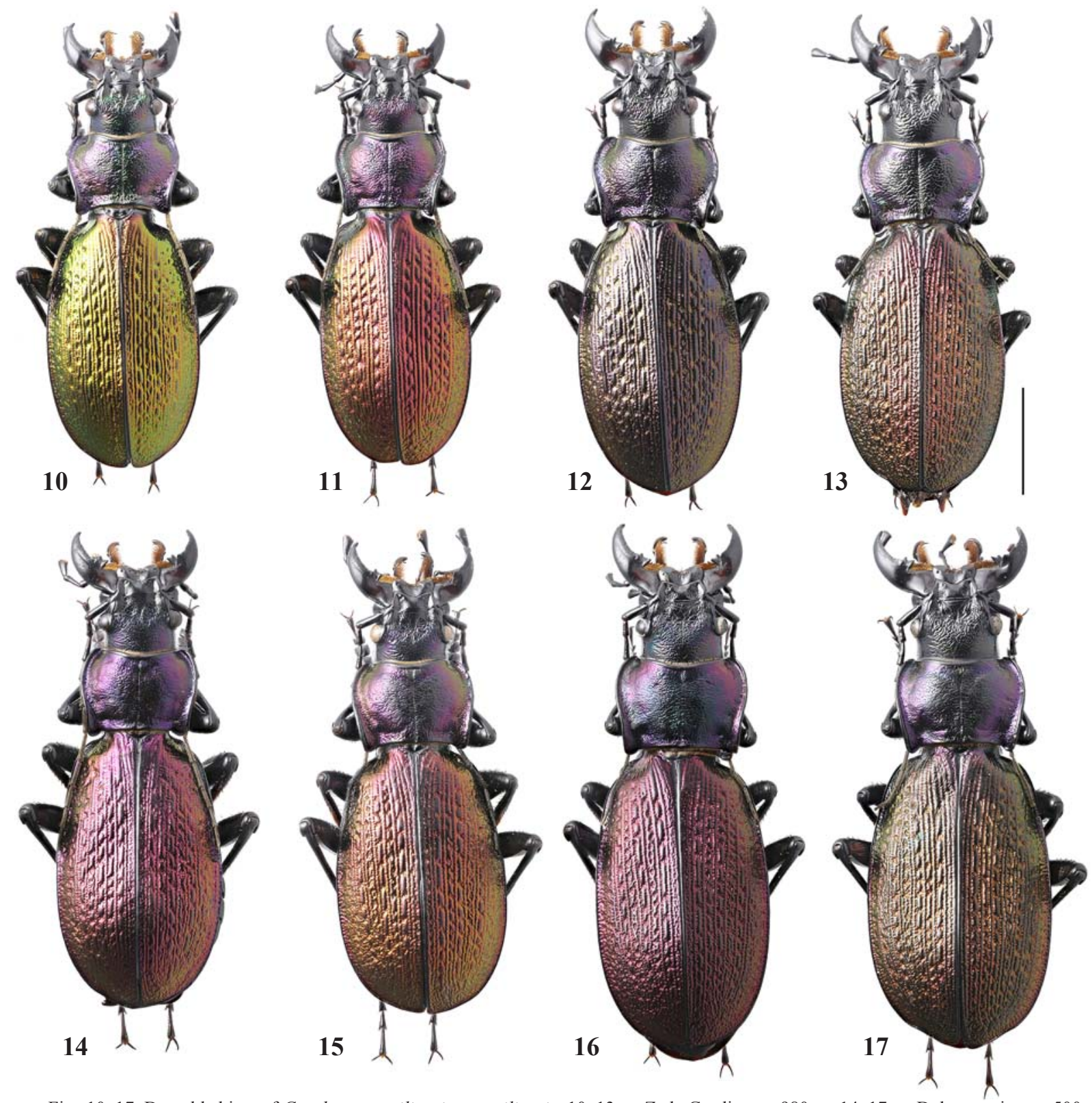

Figs 10-17. Dorsal habitus of Carabus martviliensis martviliensis: 10-13 - Zeda Gordi env., 980 m; 14-17 — Doberazeni env., 500$600 \mathrm{~m} ; 10-11,14-15$ - males; $12-13,16-17$ - females. Scale bar $10.0 \mathrm{~mm}$.

Рис. 10-17. Габитус сверху Carabus martviliensis martviliensis: 10-13 — окр. Зеда Горди, 980 м над ур. м.; 14-17 — окр. Доберазени, 500-600 м над ур. м.; 10-11, 14-15 - самцы; 12-13, 16-17- самки. Масштаб: 10,0 мм. 
hind angles faintly protruding posteriorly. Legs moderately long. Elytra oblong-ovate, convex in males, somewhat flattened in females, with prominent sculpture in both sexes, $\mathrm{EW} / \mathrm{PW}=1.3-2.3$ in both sexes; $\mathrm{EL}=22.1-25.8 \mathrm{~mm}$ in males, $23.1-27.8 \mathrm{~mm}$ in females, $\mathrm{EW}=13.1-16.6 \mathrm{~mm}$ in males, $14.8-17.5 \mathrm{~mm}$ in females, $\mathrm{EL} / \mathrm{EW}=1.5-1.7$ in both sexes.

Aedeagus as in the other Neoplectes taxa, strongly inflated medioapically and tapered just before apical lamella (Figs 18-19, 22-23); endophallus of the complicated shape, with several pronounced structures (lobes or projections).

DIFFERENTIAL DIAGNOSIS AND REMARKS. A new subspecies reliably differs from the nominotypical one in more ovate and less elongate body shape (Figs 2-9 vs. Figs 10-17), hind angles of pronotum less protruding posteriorly. It is also easily distinguishable by dorsal range of colours in all known populations. The nominotypical subspecies possesses violet or lilac colour with characteristic olive tint, green or bronze colours are observed very rare, ratio of green or bronze to standard violet individuals is about 1 to $50-100$ ones, according to our calculations, this proportion varying in different populations. A new subspecies usually possesses blue, greenish-blue, or dark violet colour, sometimes bronze or purely green individuals are also observed, though their ratio is about 1 to 50 too.

Apical lamella of aedeagus is more narrow and pointed in comparison with C. martviliensis martviliensis (Figs 18-19, 22-23 vs. 20-21, 24-25); endophallus with some minor differences in its general view too, it is less bent towards the tube of aedeagus, ventroapical lobe less developed.

Results of the discriminant analysis (Fig. 26) showed consistent differences in distribution of the studied features of C. martviliensis mzekalae ssp.n. from the nominotypical subspecies in different localities.

DISTRIBUTION AND HABITAT. A new subspecies is known from Tskhaltubo environs on the left bank of river Tskhenistskali at 520-770 m (Fig. 1). This river apparently divides ranges of two known C. martviliensis subspecies. Distribution range of $C$. martviliensis mzekalae ssp.n. spreads eastwards nearly up to Rioni valley, representative of different species-group of Neoplectes, C. szekelyi Retezar, 2011, was found on the opposite bank. The northern limit of the range is still unclear, sympatry with different consubgener $C$. titarenkoi seems to be possible at Gormagali Mt. Mass, this assumption, however, requires confirmation. A new subspecies populates moist low mountain or cloud forests on karstic

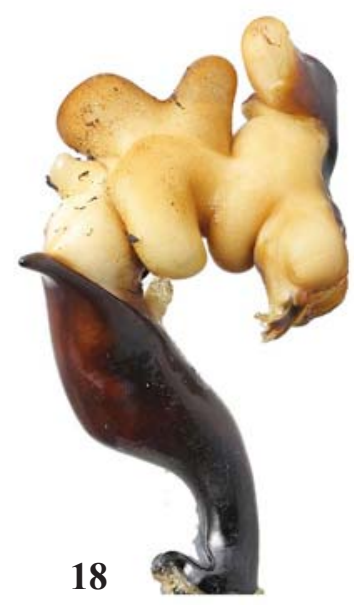

18
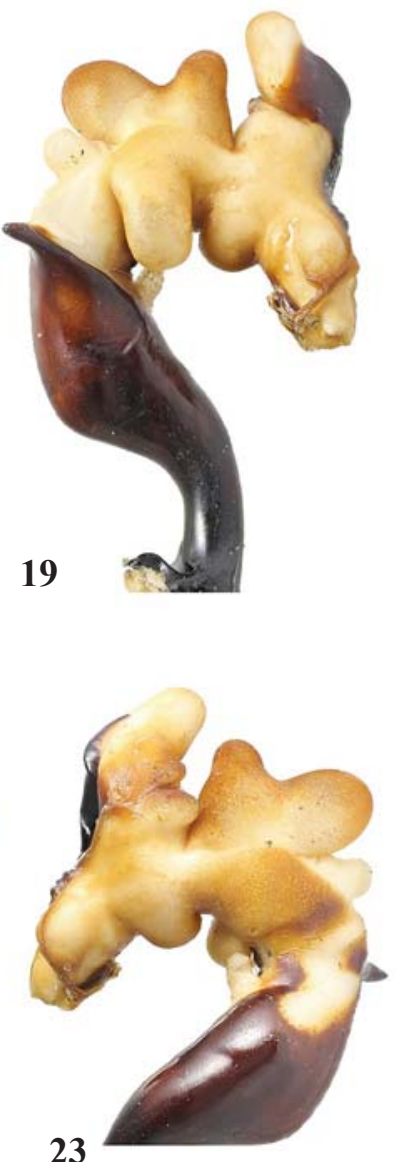
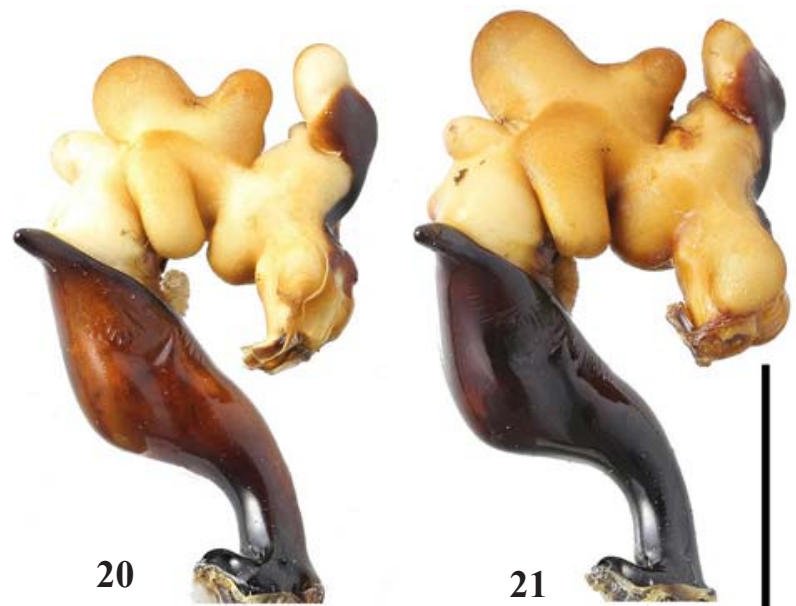

21

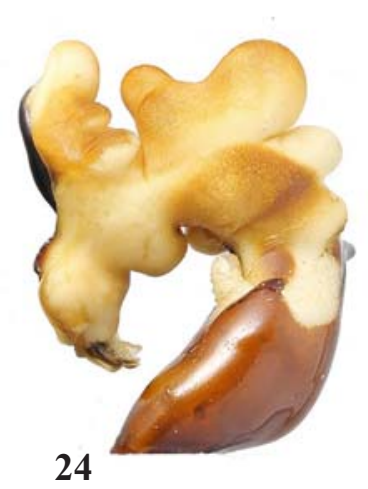

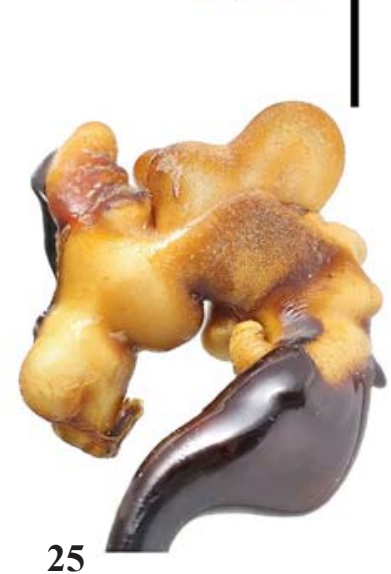

Figs 18-25. Apical portion of aedeagus and fully inflated endophallus preparation of Carabus (Neoplectes) martviliensis, right lateral view on top, left lateral view below: 18, 22 - C. martviliensis mzekalae ssp.n., Melouri env., 475 m; 19, 23 - C. martviliensis mzekalae ssp.n., Dzedzileti env. , $770 \mathrm{~m} ; 20,24-$ C. martviliensis martviliensis, Zeda Gordi env., 980 m; 21, 25 - C. martviliensis martviliensis, Doberazeni env., $600 \mathrm{~m}$. Scale bar: $10.0 \mathrm{~mm}$.

Рис. 18-25. Вершина эдеагуса и препарат полностью вывернутого внутреннего мешка Carabus (Neoplectes) martviliensis, вверху - сбоку справа, внизу — сбоку слева: 18, 22 - C. martviliensis mzekalae ssp.n., окр. Мелоури, 475 м над ур.м.; 19,23 - C. martviliensis mzekalae ssp.n., окр. Дзедзилети, 770 м над ур.м.; 20, 24 - C. martviliensis martviliensis, окр. Зеда Горди, 980 м над ур. м.; 21, 25 - C. martviliensis martviliensis, окр. Доберазени, 600 м над ур.м. Масштаб: 10,0 мм. 


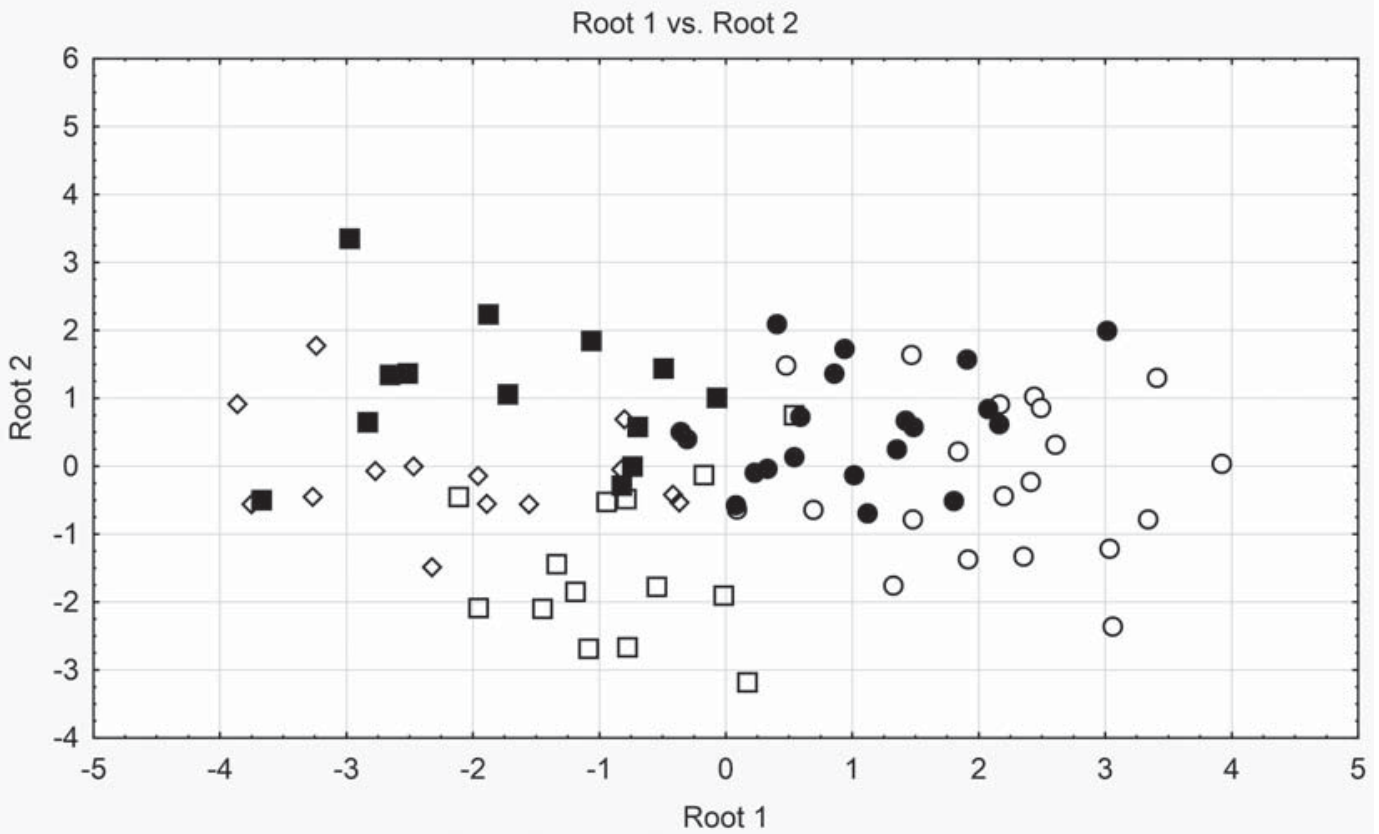

O N. martviliensis mzekalae ssp.n. Dzedzileti vic., $620 \mathrm{~m}$.

- N. martviliensis mzekalae ssp.n. Melouri vic., $475 \mathrm{~m}$.

$\diamond N$. martviliensis martviliensis Gordi vic., $900 \mathrm{~m}$.

- N. martviliensis martviliensis Ofitsari, $1800 \mathrm{~m}$.

$\square$ N. martviliensis martviliensis Tekhuri, $600 \mathrm{~m}$.

Fig. 26. Distribution of morphometric characters of Carabus (Neoplectes) martviliensis subspecies constructed using discriminant analysis based on 9 parameters (see text for measurements details).

Рис. 26. Распределение морфометрических характеристик подвидов Carabus (Neoplectes) martviliensis, построенное с использованием дискриминантного анализа, основанного на 9 параметрах (описание промеров см. текст).

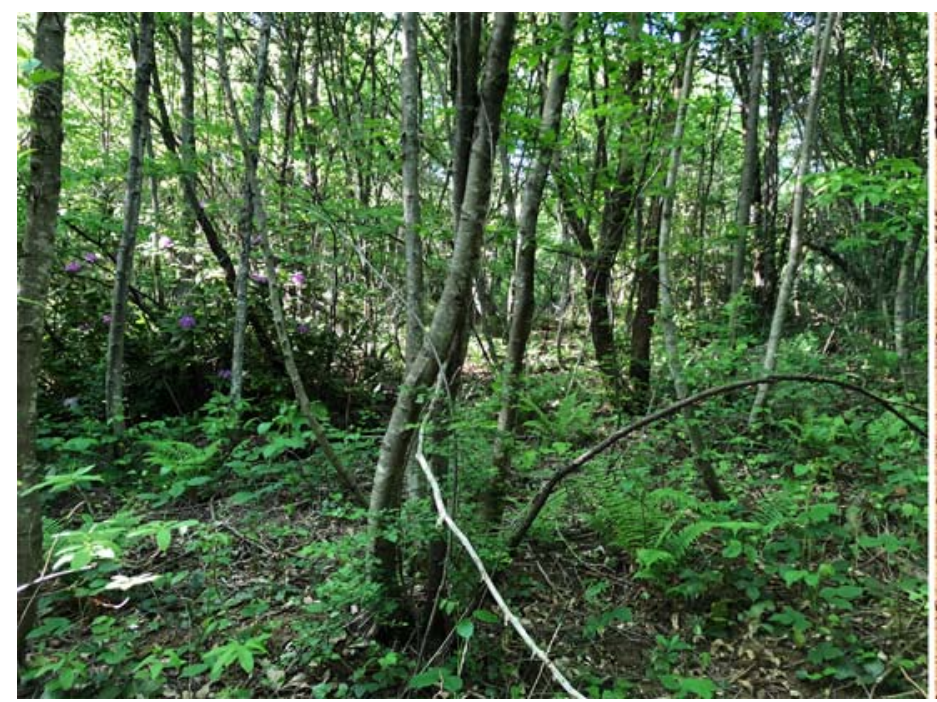

27

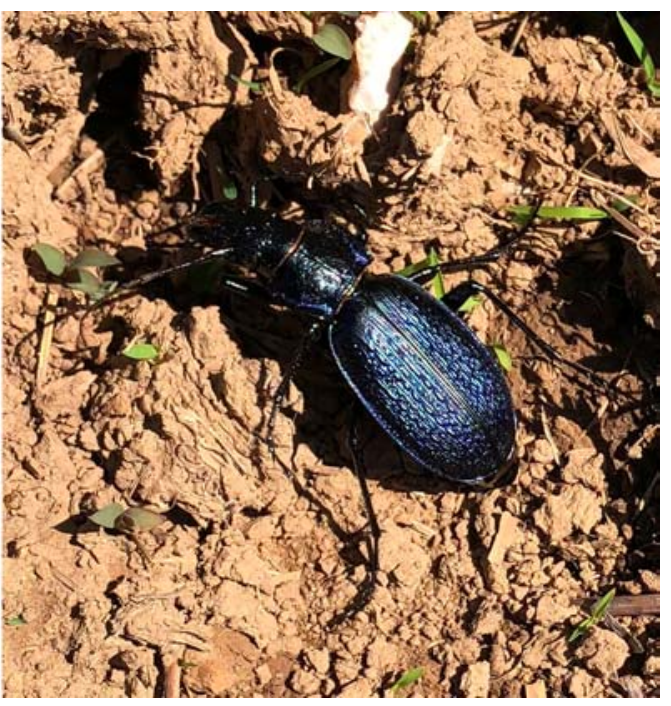

28

Fig. 27. Habitat of Carabus (Neoplectes) martviliensis mzekalae ssp.n., Dzedzileti env., $770 \mathrm{~m}$.

Рис. 27. Местообитание Carabus (Neoplectes) martviliensis mzekalae ssp.n., окр. Дзедзилети, 770 м над ур.м.

Fig. 28. Carabus (Neoplectes) martviliensis mzekalae ssp.n. in nature, Dzedzileti env., $770 \mathrm{~m}$.

Рис. 28. Carabus (Neoplectes) martviliensis mzekalae ssp.n. в природе, окр. Дзедзилети, 770 м над ур.м.

landforms, often with the very poor ground litter and dense underbrush of rhododendron (Rhododendron ponticum) and blackberry (Rubus fruticosus) (Figs 27-28). The adults are active from the beginning of May until the mid of July. Following Carabus forms occur together with this subspecies: C. (Archiplectes) protensus Shaum, 1864, C. (Tribax) 
fossiger Chaudoir, 1877, C. (Sphodristocarabus) armeniacus Mannerheim, 1830, and C. (Megodontus) septemcarinatus Motschulsky, 1840.

ETYMOLOGY. The subspecific epithet refers to the Georgian name Mzekala ( troness of the wine-making, heroine of the Georgian epos.

Acknowledgements. The authors are very grateful to $\mathrm{Mr}$. A. Zubov (Kishinev, Moldavia), Mr. B. Dubinin (Moscow, Russia), Mr. D. Safronov (Tula, Russia) for their assistance during the collecting trips to Georgia. We wish to acknowledge here also the unselfish help of Prof. K. Makarov (Moscow, Russia) in taking the photographs and preparing them for publication and help of M.Sc. E. Khomitskiy (Goryachiy Klyuch, Russia) in various technical procedures. Some aspects of the reported study were funded by the Russian Foundation for Basic Research and Administration of Krasnodar Territory, project number 19-44-230004.

\section{References}

Březina B., Huber C., Marggi W. 2017. Subtribe Carabina Latreille, 1802 // Löbl I., Löbl D. (eds.). Catalogue of Palaearc- tic Coleoptera. Revised and Updated Revision. Vol.1, Archostemata-Myxophaga-Adephaga. Leiden-Boston: Brill. P.70207.

Fominykh D.D., Zamotajlov A.S. 2014. A study on Georgian species of the Carabus Linnaeus, 1758 subgenus Neoplectes Reitter, 1885 (Coleoptera: Carabidae), with description of a new species // Euroasian Entomological Journal. Vol.13. No.6. P.522-526.

Fominykh D.D., Zamotajlov A.S., Titarenko A.Yu. 2016. Further contribution to the knowledge of Georgian species of the Carabus Linnaeus, 1758 subgenus Neoplectes Reitter, 1885, with description of a new subspecies of $C$. titarenkoi Zamotajlov \& Fominykh, 2014 (Coleoptera: Carabidae: Carabini) // Zootaxa. Vol.4179. No.3. P.561-599. doi: 10.11646/zootaxa.4179.3.10

Janovska I., Anichtchenko A.V., Erwin T. 2013. Significant new taxonomic tool for Carabidae (Insecta: Coleoptera): endophallus inflation methods revised // Caucasian Entomological Bulletin. Vol.9. No.1. P.39-42.

Retezár I. 2015. Atlas of the Carabus of the Caucasus (Coleoptera, Carabidae). Iconography, genital morphology, systematics and faunistics. Budapest: Szerzői kiadás, Mondat Kft. 134 pp. 79 maps. 238 color plates.

Shilenkov V.G. 1996. [The ground beetles of the genus Carabus L. (Coleoptera, Carabidae) of South Siberia]. Irkutsk: Irkutsk State University Publ. 80 pp. [in Russian]. 